\title{
AN EXPERIMENTAL LABORATORY STUDY ON UTILIZATION OF CERAMIC WASTE AS A PARTIAL REPLACEMENT OF COARSE AGGREGATE IN CONCRETE
}

\author{
Nishant Kumar ${ }^{1}$, Aravind Sagar $\mathbf{B}^{2}$ \\ ${ }^{I}$ M-Tech Infrastructure Construction and Management, Scholar RASTA-Centre for Road Technology, Bangalore \\ Karnataka, India \\ ${ }^{2}$ Assistant Professor, RASTA-Centre for Road Technology, Bangalore Karnataka, India
}

\begin{abstract}
In modern constructions, the usage of ceramic materials is increasing day by day in the form of tiles, sanitary fittings, electrical insulators etc. Due to its brittle nature about $30 \%$ of ceramic materials is wasted in daily production while processing, transporting and fixing. Therefore, these wastes can be used in concrete production to maintain the environment and improving the properties of concrete. Hence, the crushed waste ceramic tiles were used in concrete as a replacement for natural coarse aggregates with 10\%, 20\%, 30\%, and 40\% of substitution. After analyzing results, the optimum value of waste ceramic tile to be used within the concrete mix with a water/cement ratio of 0.4 was determined as about $20 \%$.
\end{abstract}

Keywords: Ceramic Materials, Crushed Waste Ceramic Tiles, A Replacement for Natural Coarse Aggregates, and Water/Cement Ratio of 0.4

\section{INTRODUCTION}

One of the worlds most consumed construction material is concrete. Manufacturing of concrete depends to a greater extent on availability of cement, fine and coarse aggregate. The cost of these raw materials required for concrete production has increased rapidly over time. The negative impact of the ever rising requirement for concrete involves reduction of aggregate storage, ecological imbalance and environmental degradation. The utilization of waste materials like Ceramic waste, Electronic waste and Plastic waste will not only reduce the cost of construction and even improve safe disposal of waste materials. India is ranked third in the world in production of ceramic tiles. It is predicted that wastage of ceramic tiles is around 30\% of daily production which reaches millions of tons per year. As of now ceramic waste is being disposed of by landfill. At present recycling of waste is not done in any form. The main reason behind this is non-availability of standards, lack of information, avoidance of risk, and knowledge in using ceramic wastes in construction.

\subsection{Ceramic Waste}

India is ranked third in the world in production of ceramic tiles. It is predicted that wastage of ceramic tiles is around $30 \%$ of daily production which reaches millions of tons per year. As of now ceramic waste is being disposed of by landfill. At present recycling of waste is not done in any form. The main reason behind this is non-availability of standards, lack of information, avoidance of risk, and knowledge in using ceramic wastes in construction.

\subsection{Literature Review}

Hemanth Kumar et al. (2015) Studied the effect of waste ceramic tiles in fractional replacement of CA and FA. This paper studies the partial replacement of CA and FA in concrete with crushed ceramic tiles and waste ceramic powder respectively. The work was carried out to find the behavior and performance of solid ceramic waste in concrete. The crushed waste ceramic tiles were used to partly replace CA by $10 \%$ and $20 \%$, the waste ceramic powder was also used to partly replace FA by $10 \%$ and 20 $\%$. To assess the suitability of waste ceramic tiles in concrete mix workability test, ultrasonic pulse velocity test and compressive strength test was carried out on samples it was found out that optimum compressive strength was attained for $20 \%$ replacement of crushed ceramic tiles and $10 \%$ waste ceramic powder. [1]

Hitesh Kumar Mandavi et al. (2015) studied the durability of concrete with CW as FA replacement. This paper shows the experimental investigation carried out in which $\mathrm{CW}$ was used as alternative for FA up to a range of $10 \%$ to $50 \%$ with an interval of $10 \%$. The results of compressive strength were used to determine the optimum replacement level of ceramic waste. Durability of concrete was also checked for optimum replacement level. The optimum replacement level of ceramic waste with fine aggregate was found to be at 40 $\%$. Recycled ceramic concrete was found to be more durable in chloride environment than conventional concrete. [2] 
Md Daniyal et al. (2015) In this experimental study recycled ceramic waste was used as replacement for coarse aggregate. The grading of crushed ceramic tiles was done such that it was compatible with that of natural coarse aggregate. Replacement of coarse aggregate was carried out from $0 \%, 10 \%, 20 \%, 30 \%, 30 \%, 40 \%$ and $50 \%$ with water to cement ratio at $0.4,0.5$ and 0.6. Comparison was made between workability and strength aspects with that of conventional concrete. It was found out that $30 \%$ replacement of ceramic tiles with natural coarse aggregate was found to be optimum level. The workability increases with increase in replacement Percentage. [3]

\subsection{Significance of Present Research}

- The main criteria in this research was to utilize marginal materials like ceramic waste in concrete by partially replacing it with natural crushed stone aggregates.

- M-sand is used as an alternative for natural river sand which is used as fine aggregates in concrete.

- It reduces the cost and consumption of natural raw coarse aggregates \& natural river sand as well as the depletion of the same in the environment which is causing ecological imbalance due to ever increasing demand of raw materials.

- This present research involves studying the strength of the Ceramic-waste utilized as partial replacement of coarse aggregates in the concrete for a target strength ofM40 with reduced water cement ratio.

\subsection{Objectives of the study}

The proposed research work includes studies on:

1) To utilize waste material like ceramic waste tiles as fractional replacement of crushed natural stone aggregates.

2) The influence of ceramic waste tiles on the improvement of strength behavior of concrete.

3) To understand the effect of workability of concrete mix with reused $\mathrm{CW}$.

4) To understand the strength properties such as compressive strength, split tensile strength and flexure strength by casting (cubes, cylinders and beams), curing and testing for 7, 14 and 28-day strength.

5) Cost analysis of different proportions of recycled ceramic concrete mix.

\section{METHODOLOGY}

1) Procurement of the material required for the intended study on Recycled ceramic waste concrete.

2) Determination of Physical properties of materials.

3) Crushing waste ceramic tiles by hammer.

4) Sieving crushed ceramic tiles on $12 \mathrm{~mm}$ sieve.

5) Development of trial mixes for different Mix Design.
A) Mix design was prepared based on guidelines set by IS: 10262:2009 for M40 grade of concrete.

Steps followed in mix design developments are as follows:

- Trial mixes were carried until the optimum dosage of superplasticizer is found in order to get a workable mix.

- All other ingredients except coarse aggregate $12 \mathrm{~mm}$ down were kept constant. The coarse aggregate content was taken according to the different mix proportions.

- The quantity of ceramic waste that is to be used along with CA:12 mm was done by taking its specific gravity into consideration for said volume of concrete.

- The percentage replacement of waste ceramic tile with that of coarse aggregate $12 \mathrm{~mm}$ down was fixed based on studying the previous journals in which similar work has been done, availability of ceramic waste and also processing of ceramic waste is difficult.

- The mix was prepared for different mixes having waste ceramic tile percentage within the range as shown below

- N : $0 \%$ Ceramic waste

- N1: 10\% Ceramic waste

- N2: 20\% Ceramic waste

- N3: 30\% Ceramic waste

- N4: 40\% Ceramic waste

which is used as replacement for $12 \mathrm{~mm}$ down coarse aggregates.

- The M-sand is used as fine aggregate.

- $20 \mathrm{~mm}$ and $12 \mathrm{~mm}$ down aggregates are used in the ratio 60:40.

- Water to cement ratio is fixed at 0.40 .

- Superplasticizer is added to get a workable mix after number of trials optimum dosage of superplasticizer was kept at $0.4 \%$.

6) Considering water cement ratio as 0.4 , cement was mixed along with fine and coarse aggregates, superplasticizer was added in water.

7) Slump test was conducted on fresh concrete for workability requirement.

8) Standard specimens (cube, beam and cylinder) were cast with recycled ceramic concrete by partially replacing with $12 \mathrm{~mm}$ down natural coarse aggregate preparing different mix proportionsby keeping water content constant along with fine aggregate $\mathrm{M}$ sand and coarse aggregate $60 \% 20 \mathrm{~mm}$ down.

9) The cast specimens were placed in room temperature for about $24 \mathrm{hr}$ and then demolded.

10) The demolded specimens were placed for curing in water.

11) The recycled ceramic waste concrete strength parameters were tested on (compressive, split tensile and flexure) for 7, 14, and 28 days. 


\section{EXPERIMENTAL INVESTIGATION}

\subsection{Cement}

Table 3.1 Test results of cement properties

\begin{tabular}{|l|l|l|l|}
\hline Sl.No & Description & Result & Specification \\
\hline 1 & Specific Gravity & 3.15 & - \\
\hline 2 & Consistency & $32 \%$ & - \\
\hline 3 & Fineness & $3.3 \%$ & Not exceed 10\% \\
\hline 4 & $\begin{array}{l}\text { Initial Setting } \\
\text { time }\end{array}$ & $125 \mathrm{~min}$ & $\begin{array}{l}\text { Greater than } 30 \\
\text { min }\end{array}$ \\
\hline 5 & $\begin{array}{l}\text { Final Setting } \\
\text { Time }\end{array}$ & $210 \mathrm{~min}$ & $\begin{array}{l}\text { Lesser than } 600 \\
\text { min` }\end{array}$ \\
\hline 6 & $\begin{array}{l}\text { Compressive } \\
\text { strength at 7 \& } \\
\text { 28-day strength }\end{array}$ & $\begin{array}{l}44.3 \mathrm{Mpa} \\
56 \mathrm{Mpa}\end{array}$ & $>53 \mathrm{MPa}$ \\
\hline
\end{tabular}

\subsection{Fine Aggregates}

Table 3.2 Test properties of FA properties

\begin{tabular}{|l|l|l|l|}
\hline $\begin{array}{l}\text { Sl. } \\
\text { No }\end{array}$ & Description & Result & $\begin{array}{l}\text { Specification } \\
\text { (IS 383-1970) }\end{array}$ \\
\hline 1 & Specific Gravity & 2.65 & $2.50-2.90$ \\
\hline 2 & Water Absorption & 3.65 & Less than 2\% \\
\hline 3 & Fineness Modulus & $\begin{array}{l}2.63 \\
(\mathrm{zone} \text { II })\end{array}$ & $\begin{array}{l}\text { Medium sand } \\
(2.60-2.90)\end{array}$ \\
\hline 4 & $\begin{array}{l}\text { Bulk Density } \\
\left(\mathrm{Kg} / \mathrm{m}^{3}\right)\end{array}$ & 1837.01 & $1500-1900$ \\
\hline
\end{tabular}

\subsection{Coarse Aggregates}

Table 3.3 Test properties of CA properties

\begin{tabular}{|l|l|l|l|}
\hline $\begin{array}{l}\text { Sl. } \\
\text { No }\end{array}$ & Description & Result & $\begin{array}{l}\text { Specification as } \\
\text { per } \\
\text { (IS 383-1970) }\end{array}$ \\
\hline 1 & Specific Gravity & 2.66 & $2.50-2.90$ \\
\hline 2 & $\begin{array}{l}\text { Water } \\
\text { Absorption }\end{array}$ & 0.25 & Less than $2 \%$ \\
\hline 3 & $\begin{array}{l}\text { Fineness } \\
\text { Modulus }\end{array}$ & 3.47 & $3.25-5.70$ \\
\hline 4 & $\begin{array}{l}\text { Bulk Density } \\
\left(\text { Kg/m }{ }^{3}\right)\end{array}$ & 1595.92 & $1500-1700$ \\
\hline
\end{tabular}

\subsection{Ceramic Waste}

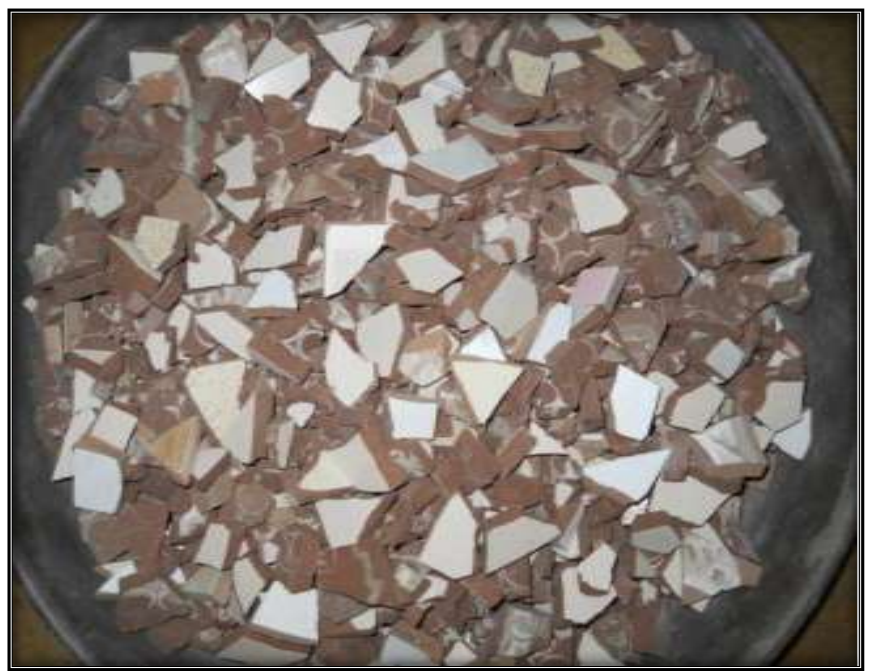

Fig 3: Pictorial representation of crushed waste ceramic tiles.

Table 3.4: Test results of ceramic tiles.

\begin{tabular}{|l|l|l|}
\hline Sl.No & Description & Result \\
\hline 1 & Specific gravity & 2.3 \\
\hline 2 & Water absorption & $6 \%$ \\
\hline 3 & Bulk Density & $1126 \mathrm{Kg} / \mathrm{m}^{3}$ \\
\hline
\end{tabular}

\subsection{Concrete Preparation and Casting}

Steps carried out while casting the recycled ceramic waste concrete are as follows:

1. Weighing of the ingredients like cement, M-Sand, Coarse aggregate, superplasticizer solution and water.

2. Weigh batching of ingredients.

3. Firstly, CA, FA and cement are added to drum mixer after weighing and the mixture is thoroughly dry mixed for about 3 minutes.

4. Superplasticizer is added to water, then water is added to drum mixer \& thoroughly mixed for about 3 minutes.

5. When the concrete is thoroughly mixed, the workability of Concrete in its fresh state was tested by slump cone method and the results obtained were recorded.

6. Fresh concrete was then poured onto the molds (cube, beam \&cylinder) in three layers, on table vibrator for about 30 second duration for each layer.

7. Surface finishing was done using trowels \& the specimens were placed in room temperature for setting for 24hrs (1 day).

8. After 24 hrs (1 day) the specimens were demolded.

9. The demolded specimens were kept for curing. 


\section{TESTS AND RESULTS}

\subsection{Cube Compressive Strength}

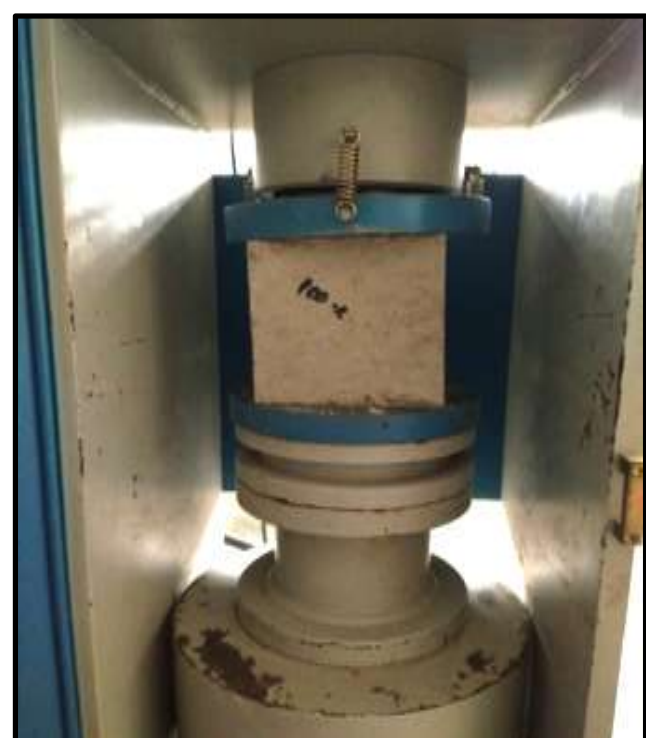

Fig 4.1: Cube Compressive strength

Table 4.1: Cube Compressive strength

\begin{tabular}{|l|l|l|l|}
\hline \multirow{2}{*}{$\begin{array}{l}\text { Mix } \\
\text { proportions }\end{array}$} & \multicolumn{3}{|c|}{ Cube Compressive strength(Mpa) } \\
\cline { 2 - 4 } N & 32.02 & 42.43 & 46.06 \\
\hline N1 & 33.14 & 43.16 & 48.03 \\
\hline N2 & 34.66 & 44.58 & 49.53 \\
\hline N3 & 30.7 & 42.5 & 47.24 \\
\hline N4 & 29.68 & 41.3 & 45.67 \\
\hline
\end{tabular}

Comparision: Compressive strength cubes v/s Mix proportions

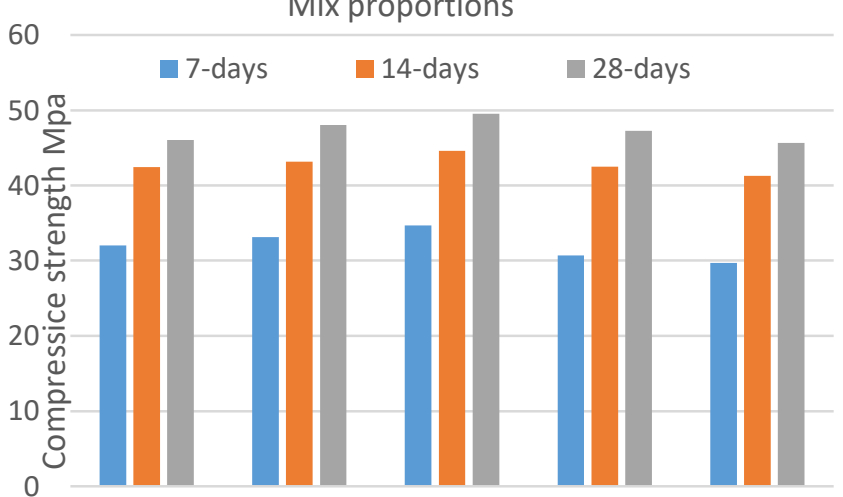

$$
\begin{array}{llll}
\mathrm{N} & \mathrm{N} 1 \underset{\text { Mix proportions }}{\mathrm{N} 2} & \mathrm{~N} 3 & \mathrm{~N} 4
\end{array}
$$

Chart 4.1: Cube Compressive Strength

\subsection{Cylinder Compressive Strength}

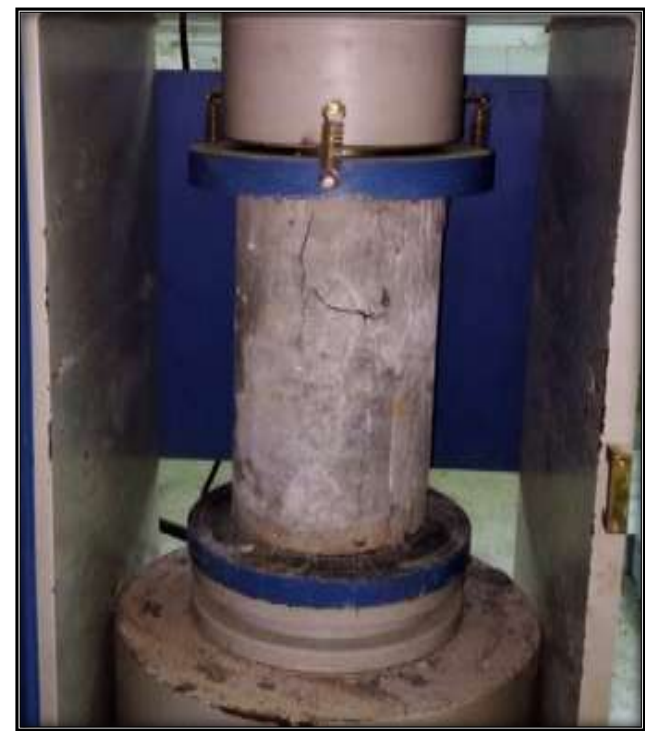

Fig 4.2: Cylinder Compressive strength

Table 4.2: Cylinder Compressive strength

\begin{tabular}{|l|l|l|l|}
\hline \multirow{2}{*}{$\begin{array}{l}\text { Mix } \\
\text { Proportions }\end{array}$} & \multicolumn{3}{|l|}{ Cylinder Compressive strength(Mpa) } \\
\cline { 2 - 4 } & 7-days & 14-days & 28-days \\
\hline N & 30.03 & 36.05 & 40.06 \\
\hline N1 & 31.32 & 37.59 & 41.77 \\
\hline N2 & 32.3 & 38.76 & 43.08 \\
\hline N3 & 30.8 & 37.8 & 41.08 \\
\hline N4 & 29.42 & 36.09 & 39.23 \\
\hline
\end{tabular}

Comparision: Compressive strength cylinder $\mathrm{v} / \mathrm{s}$ Mix proportions

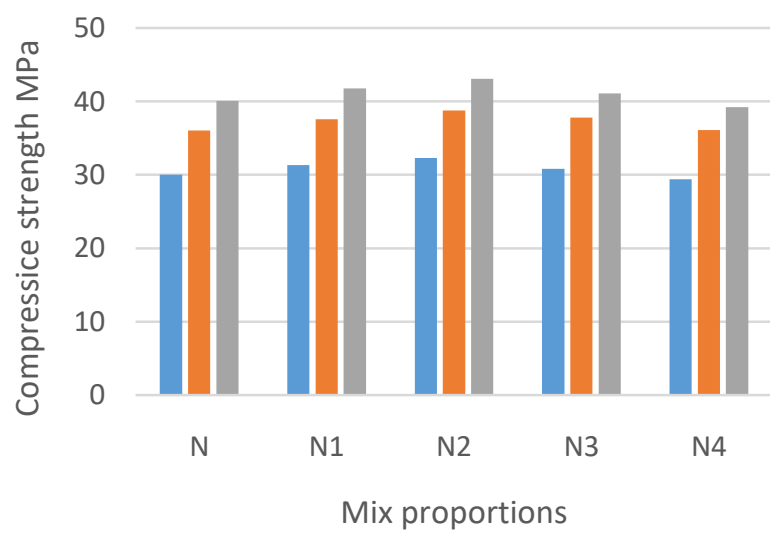

-7-days $\square$ 14-days $\square$ 28-days

Chart 4.2: Cylinder Compressive Strength 


\subsection{Split Tensile Strength}

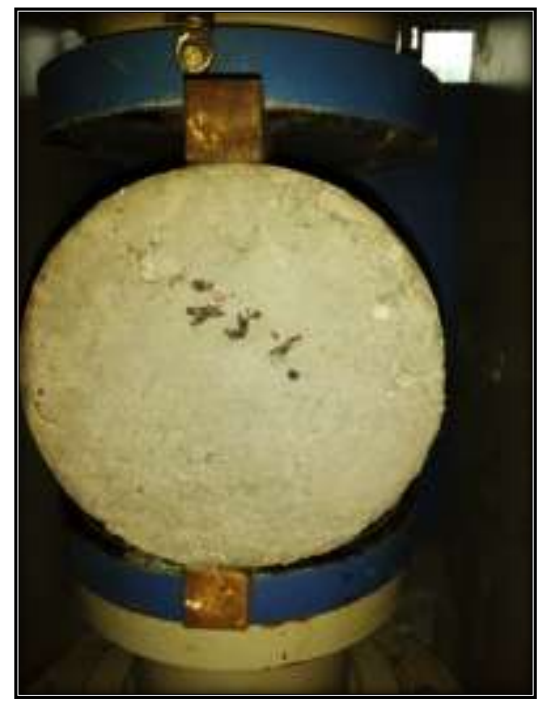

Fig 4.3 Split tensile strength

Table 4.3 Split tensile strength

\begin{tabular}{|l|l|l|l|}
\hline \multirow{2}{*}{$\begin{array}{l}\text { Mix } \\
\text { proportions }\end{array}$} & \multicolumn{4}{|l|}{ Split tensile strength(Mpa) } \\
\cline { 2 - 4 } & 7-days & 14-days & 28-days \\
\hline N & 2.42 & 3.05 & 3.11 \\
\hline N1 & 3.15 & 3.17 & 3.19 \\
\hline N2 & 3.31 & 3.32 & 3.37 \\
\hline N3 & 2.94 & 2.96 & 3.12 \\
\hline N4 & 2.53 & 2.72 & 2.95 \\
\hline
\end{tabular}

\subsection{Flexural Strength}

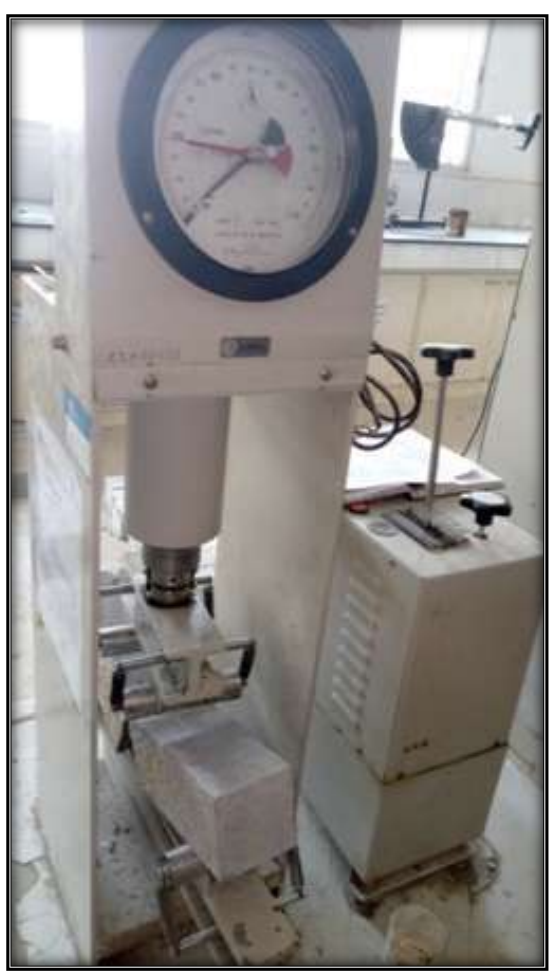

Fig 4.4 Flexural Strength
Table 4.4 Flexure strength

\begin{tabular}{|l|l|l|l|}
\hline \multirow{2}{*}{$\begin{array}{l}\text { Mix } \\
\text { Proportion }\end{array}$} & \multicolumn{4}{|l|}{ Flexure strength (Mpa) } \\
\cline { 2 - 4 } & 7-day & 14-day & 28-day \\
\hline $\mathbf{N}$ & 5.52 & 7.2 & 7.8 \\
\hline N1 & 5.9 & 6.1 & 7.08 \\
\hline N2 & 6.3 & 6.7 & 7.29 \\
\hline N3 & 6.1 & 6.3 & 6.4 \\
\hline N4 & 5.65 & 5.7 & 5.93 \\
\hline
\end{tabular}

Flexural strength comparision

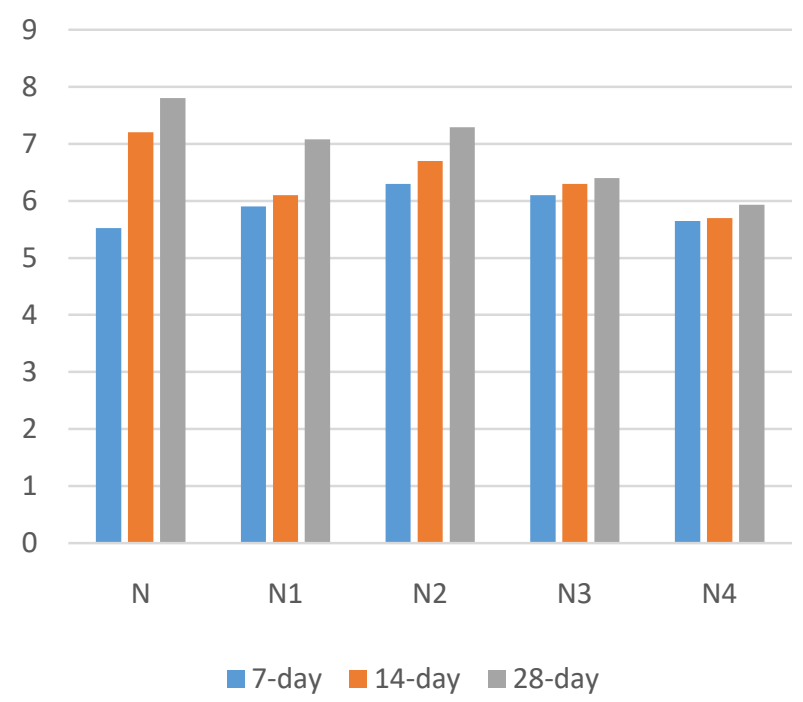

Chart 4.4 Flexure strength comparison

\subsection{Slump}

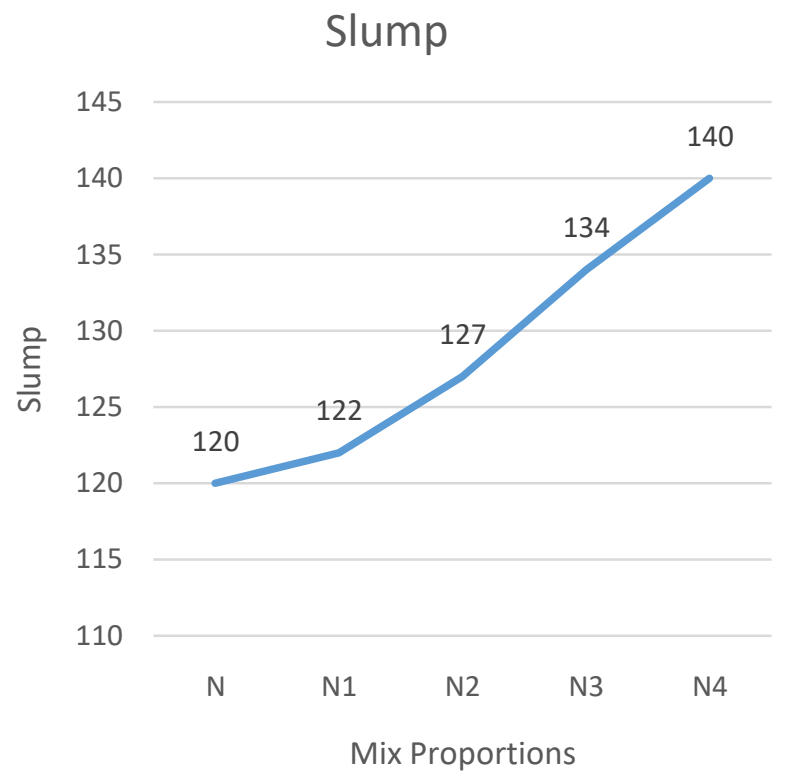




\subsection{Density}

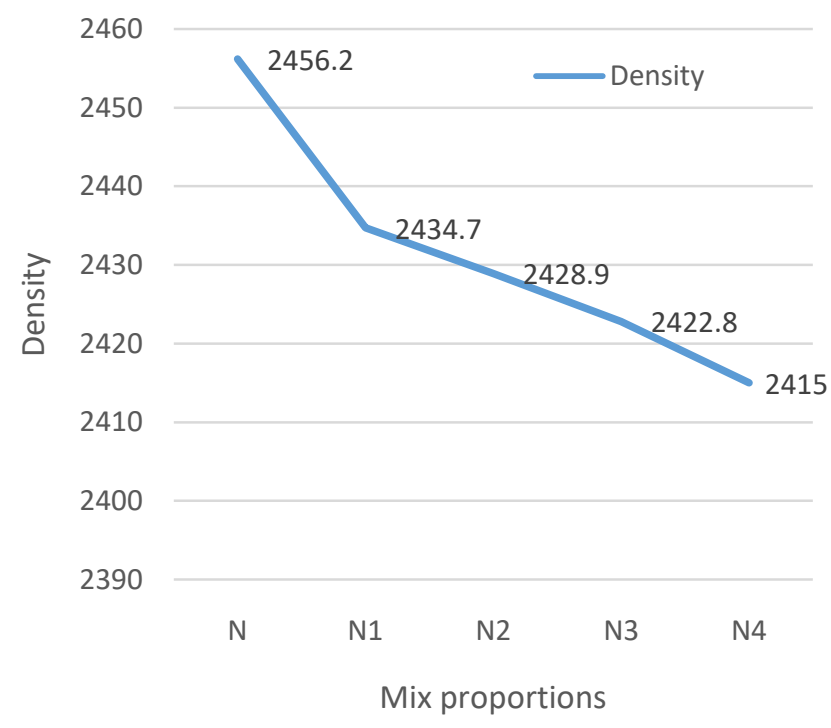

\subsection{Cost Analysis}

Table 4.5 Rates of different materials

\begin{tabular}{|c|c|c|c|}
\hline Sl.no & Material & $\begin{array}{l}\text { Rate in } \\
\text { ₹ per } \\
\text { Kg }\end{array}$ & Remarks \\
\hline 1 & Cement & 7.00 & \multirow{3}{*}{$\begin{array}{l}\text { Includes } \\
\text { transportation }\end{array}$} \\
\hline 2 & M-sand & 0.80 & \\
\hline 3 & Coarse aggregate & 0.56 & \\
\hline 4 & Ceramic waste & 1.50 & $\begin{array}{l}\text { Processing and } \\
\text { transportation }\end{array}$ \\
\hline 5 & Water & 0.05 & \multirow{2}{*}{$\begin{array}{l}\text { Includes } \\
\text { transportation }\end{array}$} \\
\hline 6 & Admixture & 150 & \\
\hline
\end{tabular}

Table 4.6: Cost of conventional concrete

\begin{tabular}{|c|c|c|c|c|}
\hline Sl.no & Material & $\begin{array}{l}\text { Content } \\
\mathrm{Kg} / \mathrm{m}^{3}\end{array}$ & $\begin{array}{l}\text { Rate } \\
\text { in } \\
\text { ₹/Kg }\end{array}$ & $\begin{array}{l}\text { Cost } \\
\text { ₹/m }\end{array}$ \\
\hline 1 & Cement & 335 & 7 & 2345 \\
\hline 2 & Natural sand & 715.5 & 1.8 & 1287.9 \\
\hline 3 & $\begin{array}{l}\text { Coarse } \\
\text { aggregate }\end{array}$ & 1281.6 & .56 & 717.69 \\
\hline 4 & Water & 167.45 & .05 & 8.3 \\
\hline 5 & Admixture & 1.34 & 150 & 201 \\
\hline \multicolumn{4}{|c|}{ Total Cost in ₹ $/ \mathrm{m}^{3}$} & 4559.89 \\
\hline
\end{tabular}

\section{Cost comparision}

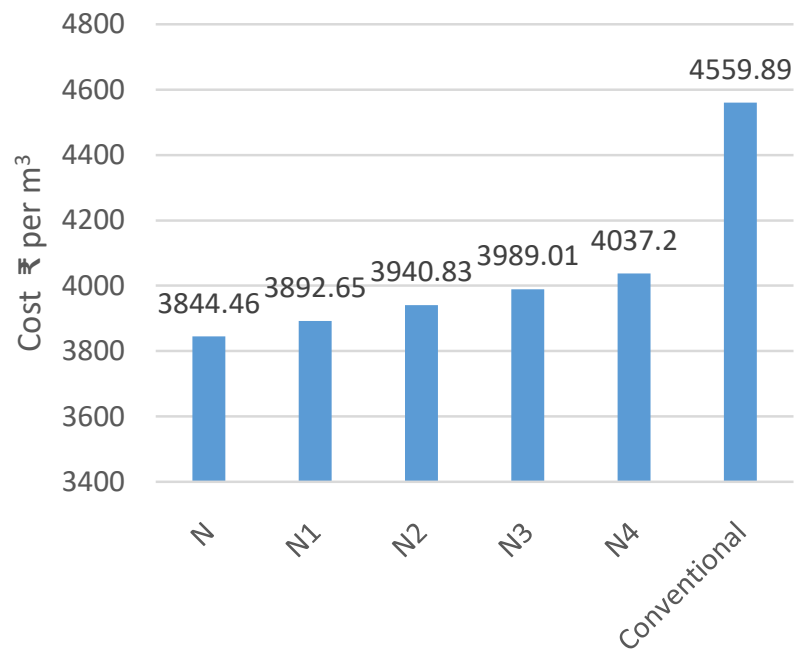

Mix proportions

Chart 4.5 Cost comparison of different mix proportions

\section{CONCLUSION}

1. The workability of RCW mixes increases with increases in percentage replacement of Ceramic waste with $\mathrm{CA}$ content.

2. The strength properties like compressive strength, split tensile strength, and flexural strength of RCW mixes increases with the increase in percentage of ceramic content from the $0 \%$ to $20 \%$ and further decreases.

3. The test results show that at $20 \%$ replacement of ceramic waste with CA:12 (N2: 20 \% CW-80\% CA) gives better results. At 28 days curing, compressive strength $49.53 \mathrm{MPa}$ (cube), 43.08 $\mathrm{MPa}$ (cylinder), split tensile strength $3.37 \mathrm{MPa}$, and flexural strength 7.29 MPa is achieved.

4. The slump values of the different mixes increases with the increase of the $\mathrm{CW}$ content on an average of $10 \%$ improvement can be observed while handling the concrete mixes.

5. The Density of RCW mixes decreases with increase in percentage of $\mathrm{CW}$ content observed that on an average of $1.25 \%$ variation between all the different mixes.

\subsection{Scope for Future Work}

- Further study can be done using other ceramic waste materials such as clay bricks and flower pot.

- Further study can be carried out on Durability, permeability, and water absorption.

- Evaluation of strength at longer duration.

- Further study can be continued on the partial replacement of the natural fine aggregate by ceramic waste. 


\section{REFERENCES}

[1]. Hemanth kumar, Ananda Ramakrishna, Sateesh Babu, Guravaiah, Naveen, Jani (2015) "Effect of Waste Ceramic Tiles in Partial Replacement of Coarse and Fine Aggregate of Concrete". International Advanced Research Journal in Science, Engineering and Technology Vol. 2, Issue 6, June 2015.

[2]. Hitesh Kumar Mandavi, Vikas Srivastava, V.C. Agarwal (2015) "Durability of concrete with ceramic waste as fine aggregate replacement". International Journal of Engineering and Technical Research (IJETR) ISSN: 23210869 (O) 2454-4698 (P), Volume-3, Issue-8, August 2015

[3]. Md Daniyal, Shakeel Ahmad (2015) "Application of Waste Ceramic Tile Aggregates

in Concrete". International Journal of Innovative Research in Science, Engineering and Technology Vol. 4, Issue 12, December 2015.

[4]. IS: 2386-1963, "Methods of Test for Aggregates for Concrete (Part III) Specific Gravity, Density, Voids, Absorption and Bulking. Indian standard" Bureau of Indian standards, New Delhi.

[5]. IS: 383- 1970, "Specification for Coarse and Fine Aggregate from Natural Source for Concrete", Bureau of Indian standards, New Delhi.

[6]. IS 516 - 1959, "Indian Standard Methods of Tests for Strength of Concrete (Incorporating Amendment Nos. 1 \& 2)", Bureau of Indian standards, New Delhi.

[7]. IS 12269 - 1987, "Ordinary Portland Cement,53 Grade - Specification", Bureau of Indian standards, New Delhi.

[8]. IS 10262 - 2009, "Guidelines for concrete mix design proportion", Bureau of Indian standards, New Delhi.

[9]. IS 456 - 2000, "Indian code of practice for plain and reinforced concrete", Bureau of Indian standards, New Delhi.

[10]. M. S. Shetty, Concrete technology theory and practice, S Chand \& Company Ltd, 2011.

\section{BIOGRAPHIES}

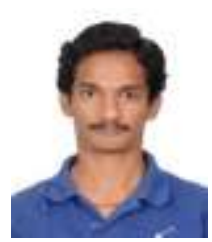

Nishant Kumar M.Tech (Infrastructure Construction and Management), Scholar RASTA-Centre for road technology, Karnataka, India

E- kulkarninishu@gmail.com

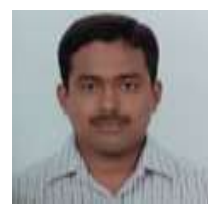

Aravind Sagar B Assistant Professor RASTA-Centre for road technology, Karnataka, India E-aravindsagar@hotmail.com 